\title{
ОГЛЯд
}

УДК 615.322:582.683.2:615.214.3

DOI 10.11603/mcch.2410-681X.2021.i2.12048

S. A. Tsiumpala ${ }^{1}$, K. M. Starchevska ${ }^{1}$, V. I. Lushchak ${ }^{1,2,3}$ VASYL STEFANYK PRECARPATHIAN NATIONAL UNIVERSITY ${ }^{1}$, IVANO-FRANKIVSK I. HORBACHEVSKY TERNOPIL NATIONAL MEDICAL UNIVERSITY² RESEARCH AND DEVELOPMENT UNIVERSITY ${ }^{3}$ IVANO-FRANKIVSK

\section{POTENTIAL USE OF SULFORAPHANE AS A NEUROPROTECTOR}

Introduction. Under normal conditions, oxidative stress and proinflammatory processes are tightly controlled. However, during neuroinflammation and overproduction of reactive oxygen species (ROS), homeostasis is disrupted, which may lead to development of Alzheimer's disease, Parkinson's disease and other neurodegenerative disorders. Inflammatory processes may result in neurodegenerative disorders. Sulforaphane is an isothiocyanate compound which has potential for treatment of neurodegenerative disorders. Its therapeutic potential is based on the ability to activate transcription of genes, that regulate protective cellular mechanisms. The importance of studying sulforaphane as a neuroprotector is based on the fact, that dementias are the seventh leading cause of death globally and actively progress due to aging of human population. In this review, the anti-inflammatory effects of sulforaphane in the brain and its use as a potential neuroprotector in the treatment of neurodegenerative diseases are discussed.

The aim of the study - to review available literature sources on the potential use of sulforaphane to prevent or mitigate neuroinflammation.

Conclusions. Economic and technological development of mankind and the improvement of the general quality of life leads to prolongation of human life. But, achievements of longevity give new challenges to humanity. In young age and early adulthood, the organisms can relatively easily maintain homeostasis, then in old age intensification of oxidative stress and inflammatory processes can lead to the development of dementias and mental disorders. What should we do now to save clear mind in old age? In this review, sulforaphane is considered to be a potential neuroprotector. Biologically active supplements and drugs containing sulforaphane can weaken up inflammatory processes in the brain and in the body in general, and therefore they can be used for prevention and treatment of neurodegenerative diseases.

KEY WORDS: neuroprotector; sulforaphane; neuroinflammation; neurodegenerative diseases.

Sulforaphane is an isothiocyanate compound, that occurs in broccoli (Brassica oleracea var. Italica) and in other cruciferous vegetables such as cabbage (Brassica oleracea var. Capitata) or brussels sprout (Brassica oleracea var. gemmifera) and protects plants from insects [1]. Glucoraphanin is a biologically inactive precursor of sulforaphane. During disruption of plant tissues, i.e., by insect attack, vacuoles that contain glucoraphanin are damaged and their content is released. A cytosol resident enzyme myrosinase hydrolyses glucoraphanin to glucose and isothiocyanates, particularly to sulforaphane [2]. Sulforaphane-containing products are used for prevention of cancer and other diseases that are linked with inflammation. Its therapeutic potential is based on the ability to activate transcription of genes, that regulate protecting activities of cells against inflammation, oxidative stress and DNA damage [3].

(c) S. A. Tsiumpala, K. M. Starchevska, V. I. Lushchak, 2021.
Nowadays, the link between inflammation and neurodegenerative diseases is well known [4-7]. This paper aims to highlight the potential use of sulforaphane to prevent or mitigate neuroinflammation.

DEVELOPMENT OF NEUROINFLAMMATION. Inflammation includes number of physiological and pathological processes coordinated by mediators that form complex regulatory networks. Neuroinflammation occurs due to overstimulation of the adaptive immune system in the brain [8]. The effectors of a neuroinflammatory response are resident immune cells (microglia) in the brain that can be activated by the inflammatory mediators [9]. Inflammation is accompanied by an overproduction of reactive oxygen species (ROS) that may lead to the failure of antioxidant systems and intensification of oxidative stress [10]. Further, the chronic oxidative stress enhances neurodegenerative processes 
in the brain [11]. Reactive oxygen species has comprehensive impact on the organism, they are always present there and moderate amounts of ROS activate signalling pathways that modulate processes such as NF-kB transcriptional activity, autophagy, production of DNA-based neutrophil extracellular traps, wound healing and repairing processes $[12,13]$.

Blood-brain barrier (BBB) has an essential role in protection of the brain against pathogens. This barrier separates the central nervous system from peripheral fluid. Disruption of BBB and dysfunction of leukocyte migration participates in the development of Parkinson's and Alzheimer's diseases [14]. With aging, BBB integrity is disturbed that increases the risk of neurodegenerative disorders [15].

Development of inflammation involves two groups of immune cells: brain-resident macrophages and blood-derived leucocytes (Fig. 1). Microglia presents up about $10-20 \%$ of the glial content in the CNS. Also, they are the brain-resident immune cells of the CNS and form the first protecting line against pathogens [16]. In steady state microglia have large number of functions such as secretion of insulin-like growth factor 1 at development of neurons and regulation of neuroplasticity. Moreover, microglia maintain neurogenesis in adult age [17-19].

Blood-derived leucocytes that penetrate the BBB are exposed to different challenges from peripheral tissues and organs. T cells, central regulators of major adaptive immune responses, and other cells of the immune system are confronted with neurons and glial cells that have low expression of Major Histocompatibility Complex (MHC) Class I (MHCl) [20]. Lack of $\mathrm{MHCl}$ expression in neurons and glial cells induces attack of killer cells from the innate immune system, namely natural killer cells (NK) [21].

In the review of B. Hart three stages of autoimmune response were established in the brain and the role of the immune system in the development of neurodegenerative diseases was noted: (1) development of autoreactive lymphocytes occurs in the tissues other than the brain, $T$ and $B$ cells are activated in the lymphoid organs, then they drain to the brain but before entering the central nervous system autoreactive $T$ cells undergo phenotypic changes in the spleen; (2) lymphocytes cross BBB, $T$ cells and monocytes/macrophages bypass BBB via post-capillary venules or cerebrospinal fluid; (3) development of autoimmune response [21].

Further, the interaction of $T$ cells from peripheral organs with local antigen presenting cells, i.e., microglia cells, leads to a complex cascade of pathophysiological processes, such as formation of plasma cells, small amounts of antibodies against myelin proteins enter the CNS, bind to the myelin sheath and allow the macrophage to recognize it via its high-affinity Fc receptors [22].

R. Santín-Márquez and colelagues [23] highlighted the process of autoimmune response development: during autoimmune response the release of proinflammatory caspase-1 induces the activation of proinflammatory cytokines, such as IL-1b, IL-18, and IL-33. The released cytokines

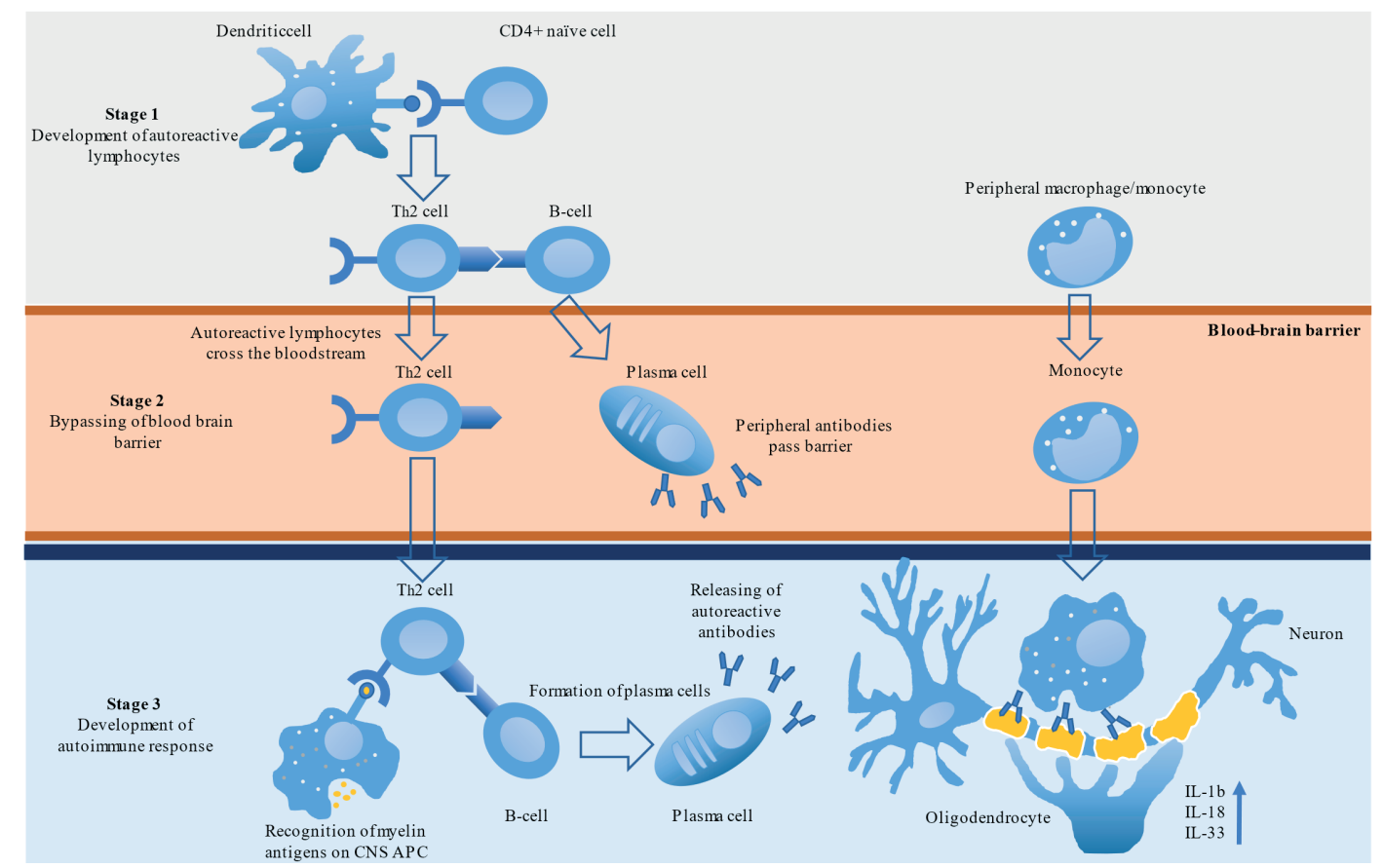

Fig. 1. Development of neuroinflammation. Autoreactive leukocytes bypass blood-brain barrier. The myelin antigens are presented to Th2 cells, which induce the formation of plasma B cells, that produce antibodies against myelin sheath. 
induce tissue swelling and disruption of the bloodbrain barrier, which leads to the long-term development of inflammation and the myelin sheath disruption in cells of the nervous system [15]. Also, the myelin antigens are presented to autoreactive $T_{h} 2$ cells which induce formation of plasma cells and antibodies against myelin sheath. Prolonged neuroinflammation may lead to Alzheimer's disease, Parkinson's disease and amyotrophic lateral sclerosis $[24,25]$.

At normal aging, the brain shows signs of enhanced oxidative stress and inflammatory processes, therefore maintaining of homeostasis is among potential treatments against excessive inflammation and oxidative stress [26].

MECHANISM OF ACTION OF SULFORAPHANE. There are two main mechanisms involved in the regulation of the antioxidant and inflammatory responses in the brain: Nrf2/Keap1 and NF-KB signalling pathways (Fig. 2).

Nuclear factor kappa-light-chain-enhancer of activated $B$ cells (NF-KB) is a family of seven structurally linked transcription factors that control gene network expression in the stress response and inflammation. NF-KB is activated by proinflammatory cytokines, ROS, pathogens and DNA damage [27, 28]. NF-KB plays an important role in the innate and adaptive immune responses, it is necessary for the normal differentiation of blood cells and the formation of the secondary lymphoid organs [29]. The importance of NF-KB in the signal transmission from CD40, toll-like receptors and the B-cell receptor was demonstrated in mice, in which the genes of individual members of the NF-kB family are inactivated [30].
There are two ways for activation of NF-KB signaling pathways: classical (canonical) and alternative (noncanonical) pathways that lead to activation of the individual subunits and downstream genetic responses. Classical signaling pathway begins with $\mathrm{B}$-cell and T-cell antigen receptors as well as cytokine receptors. Also, it controls nuclear levels of the prototypical NF-kB complex. Under normal conditions, NF-KB/Rel proteins are bound and inactivated in the cytoplasm primarily by IKB proteins, that inhibit NF-KB nuclear translocation ability [31]. Limited proteolysis of the IKB proteins is the canonical pathway for NF-kB activation [32]. Proinflammatory cytokines, tumor necrosis factor (TNF), growth factors activate the IKK complex (IKK $\beta$, IKK $\alpha$ and NEMO) through downstream activation of Mitogen-activated protein kinase kinase kinase 7 (TAK1) and RAC-alpha serine/threonine-protein kinase (Akt1) that phosphorylate IKB proteins $[31,33]$. This signal is transmitted to the IKK complex, which phosphorylates IKB proteins. The IKK $\beta$ subunit performs the catalytic function. Phosphorylated IKB proteins are cleaved by the proteasome, which allows p50/p52/p65 allocate into the nucleus. In the alternative NF-kB pathway, NF-KB2 p100/RelB is inactive in the cytoplasm. Signalling begins with activation of the NIK kinase by LTRR, CD40 and BR3 receptors which, in turn, activates IKKa complexes, that phosphorylate NF-kB2 p100. This leads to ubiquitination of NF-KB2 p100, proteasomal processing of NF-kB2 p52 and translocation of p52 into the nucleus [34]. In both pathways, activated NF-kB rapidly enters the nucleus to initiate expression of target genes by inducing assembly of active promoters and recruiting

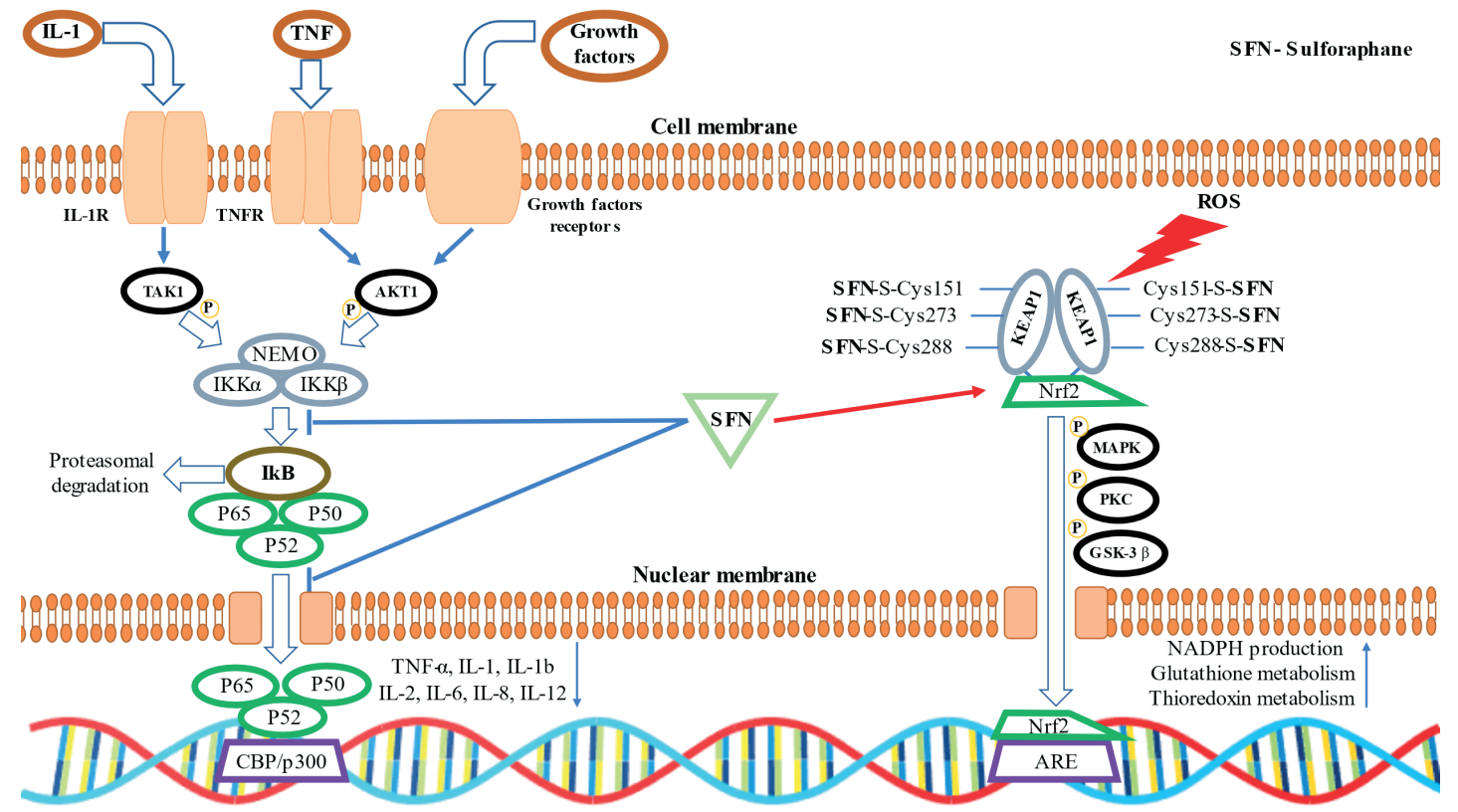

Fig. 2. General scheme of action of sulforaphane in NF-kB (classical pathway) and Nrf2. 
CBP/p300 coactivator family to target gene promoters [35]. This up-regulates expression of TNFa, IL-1, IL-1b, IL-2, IL-6, IL-8 and IL-12 [31, 34, 36]. Operation of both, canonical and non-canonical pathways, in the cell is interconnected [33, 37]. Thus, the classical and non-classical activation pathways are related and the classical pathway disruption leads to violation of the non-classical regulatory pathway.

Sulforaphane inhibits the NF-KB signaling pathway at various stages of its absorption but molecular mechanisms are currently unknown. It is unclear whether sulforaphane activates expressionn of all NF-KB target genes or selected ones. Inhibition of NF-kB leads to decrease in the expression of pro-inflammatory cytokines TNF $\alpha$, IL-1, IL-1b, IL-2, IL-6, IL-8 and IL-12 and, therefore, diminished proinflammatory processes $[23,38,39]$.

Nuclear factor E2-related factor 2 (Nrf2) is a transcription factor localized in the cytosol and that regulates stress-inducible activation of the cells [40]. Nrf2 modulates gene transcription of the glutathione and thioredoxin antioxidant system components as well as enzymes involved in the response to oxidative stress [41]. Additionally, Nrf2 is largely responsible for other processes in the cells, such as autophagy, drug metabolism and unfolded protein response [42]. Nrf2/Keap1 is a pathway that protects neuronal cells against ROS and other reactive species. Thus, enhancing of Nrf2/Keap1 activity is an indicator of oxidative stress in the brain [43].

Kelch-like ECH-associated protein 1 (Keap1) is responsible for regulation of Nrf2 [44]. Keap1 forms a homodimer that is involved in sequestering of Nrf2 in the cytosol and inactivates the latter. Keap1 is a protein that contains thiol groups in reactive cysteine residues. Although it shuttles between cytoplasm and nucleus, it is mostly located in the cytoplasm [44]. Without oxidation Nrf2 is unable enter the nucleus, thus, transcription of antioxidant system components is limited [45].

The mechanism of Nrf2 restriction was discovered by A. Kobayashi and colleagues [46]. In the normal state, Nrf2 is inactivated by proteolysis to prevent its harmful action. Nrf2 is sequestered in the cytosol by the Keap1 homodimer, which acts as a substrate adaptor for the ubiquitination of Nrf2 in a cullin-3 (Cul3) dependent manner. The association with Keap1 facilitates the proteasomal degradation of Nrf2. Bound to Keap1 Nrf2 undergoes poly-ubiquitination via the Cul3 E3 ligase and is subjected to degradation by the $26 \mathrm{~S}$ proteasome. This results in low content of Nrf2 in the cell. These degradative processes are energy-dependent but under stressful conditions, the cell can quickly handle it [46].

The studies of A. Dinkova-Kostova with colleagues [47] gave the first evidence that electro- philes are capable of separating Keap1 from the Neh2 region of Nrf2. They deduced that the sensor must be Keap1, as the Neh2 region does not contain cysteine residues. Nrf2 is active after the Keap/ Nrf2 complex dissociation, which can be promoted by electrophilic or oxidative factor $[48,49]$. Thiols are targets for electrophiles that can modify the structure of Keap1 and disrupt its normal functioning as a ubiquitinating element for Nrf2. Therefore, Keap1 may be an oxidative stress marker [50].

After entering the nucleus, Nrf2 forms a heterodimer with MAFF, MAFG or MAFK and binds to the antioxidant response element (ARE) in the upstream promoter region of the target genes and initiates their transcription [51].

He and colleagues [52] listed next Nrf2 regulatory abilities in metabolic processes: (1) induction of expression of genes encoding enzymes of pentose phosphate pathway which produces NADPH; (2) promotion of amino acid metabolism, especially de novo serine biosynthesis; (3) regulation of degradation and biosynthesis of triacylglycerides and phospholipids, lipid transport and fatty acid oxidation; (4) regulation of heme and iron metabolism; (5) regulation of unfolded protein response, proteostasis and autophagy; (6) induction of ex-

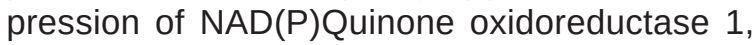
glutathione-S-transferases and glutamate cysteine ligase [52].

Sulforaphane is able to interact with cysteine residues of Keap1 (Cys151, Cys273, Cys288), which causes a "simulation" of ROS attack under oxidative stress conditions. When Nrf2 is not degraded, MAPK, PKC, GSK-3b (protein kinase enzymes) activate Nrf2 via phosphorylation, then Nrf2 is transferred into the nucleus and interacts with the Maf protein [53]. Phosphorylated Nrf2 binds to Maf and activates ARE which results in the expression of antioxidant and anti-inflammatory enzymes. In this manner, sulforaphane activates Nrf2 and represses development of neuroinflammation and neurodegeneration [23].

The biological activity of sulforaphane at the cellular level is well studied. Sulforaphane is able to reduce inflammation and oxidative stress intensity through intracellular regulatory mechanisms. Decreased concentration of pro-inflammatory cytokines along with enhanced antioxidant response leads to the inhibition of inflammatory processes and the restoration of homeostasis in the brain. However, there are difficulties in transportation sulforaphane to the site of its therapeutic action and its practical using.

POTENTIAL USE. Due to the broad spectrum of action of sulforaphane, consumption of products that contain glucoraphanin and sulforaphane can 
be beneficial for the organism. Cruciferous vegetables are known to prevent colorectal adenoma development due to high content of isothiocyanates [54]. Also, diets rich in broccoli, are associated with lower risk of bladder cancer [55]. Broccoli (Brassica oleracea var. Italica) is one of the most common plants containing glucoraphanin and sulforaphane [56]. The amount of glucoraphanin and sulforaphane in broccoli is in the range of $1.4-32.9 \mu \mathrm{g} / \mathrm{g}$ of raw weight, the highest content was found in flowers and seeds [57].

The process of isolation and purification of sulforaphane is important for work with it and high-performance liquid chromatography seems is the best one in this context [58]. A solid-phase extraction with nanostructured silicon dioxide SBA-15 can be used for pre-concentration of sulforaphane which was tested with broccoli [59].

Mice treated with a glucoraphanin-enriched diet at a young age had less cognitive dysfunction and oxidative stress signatures in adulthood [60]. Administration of sulforaphane to the abdominal cavity of rats led to the activation of Nrf2, reduced intensity oxidative stress and neuroinflammation. In addition, sulforaphane application restored memory function in rats with memory dysfunction due to okadaic acid treatment [61]. Administration of sulforaphane by intracerebroventricular injection to bypass BBB prevented spatial memory dysfunction in mice [62]. Oral administration of aqueous extracts of broccoli prevented the toxic effects of vincristine, a drug from the group of alkaloids, which has anticancer abilities with concomitant induction of oxidative stress [63].

CONCLUSION. Economic and technological development of mankind and the improvement of the general quality of life leads to the prolongation of human life. But, achievements of longevity give new challenges to humanity. In young age and early adulthood, the organisms can relatively easily maintain homeostasis, then in old age intensification of oxidative stress and inflammatory processes may lead to the development of dementias and mental disorders. What should we do now to save clear mind in old age? In this review, sulforaphane is considered to be a potential neuroprotector. Biologically active supplements and drugs containing sulforaphane can weaken up inflammatory processes in the brain and in the body in general, and therefore they can be used for prevention and treatment of neurodegenerative diseases.
LIST OF LITERATURE

1. Vanduchova A. Isothiocyanate from broccoli, sulforaphane, and its properties / A. Vanduchova, P. Anzenbacher, E. Anzenbacherova // Journal of Medicinal Food. - 2019. - No. 22. - P. 121-126. - Access mode : https://doi.org/10.1089/jmf.2018.0024.

2. Halkier B. A. Biology and biochemistry of glucosinolates / B. A. Halkier, J. Gershenzon // Annual Review of Plant Biology. - 2006. - No. 57. - P. 303-333. Access mode : https://doi.org/10.1146/annurev.arplant. 57.032905.105228

3. Juge N. Molecular basis for chemoprevention by sulforaphane: A comprehensive review / N. Juge, R. F. Mithen, M. Traka // Cellular and Molecular Life Sciences. - 2007. - No. 64. - P. 1105-1127. - Access mode : https://doi.org/10.1007/s00018-007-6484-5.

4. Fischer R. Interrelation of oxidative stress and inflammation in neurodegenerative disease: role of TNF / R. Fischer, O. Maier // Oxidative Medicine and Cellular Longevity. -2015. - No. 2015. -P. 1-18. -Access mode : https://doi.org/10.1155/2015/610813.

5. Association of stress-related disorders with subsequent neurodegenerative diseases $/ \mathrm{H}$. Song, J. Sieurin, K. Wirdefeldt [et al.] // JAMA Neurology. - 2020. No. 77. - P. 700-709. - Access mode : https://doi. org/10.1001/jamaneurol.2020.0117.
6. Oxidative stress and neuroinflammation potentiate each other to promote progression of dopamine neurodegeneration / J. He, G. Zhu, G. Wang, F. Zhang // Oxidative Medicine and Cellular Longevity. - 2020. No. 2020. - P. 1-12. - Access mode : https://doi. org/10.1155/2020/6137521.

7. Blach-Olszewska Z. Mechanisms of over-activated innate immune system regulation in autoimmune and neurodegenerative disorders / Z. Blach-Olszewska, J. Leszek // Neuropsychiatric Disease and Treatment. 2007. - No. 3. - P. 365-372.

8. Garaschuk O. Healthy brain aging: Interplay between reactive species, inflammation and energy supply / O. Garaschuk, H. M. Semchyshyn, V. I. Lushchak. // Ageing Research Reviews. - 2018. - No. 43. P. 26-45. - Access mode : https://doi.org/10.1016/j. arr.2018.02.003.

9. Medzhitov R. Origin and physiological roles of inflammation / R. Medzhitov // Nature. -2008. - No. 454. P. 428-435. - Access mode : https://doi.org/10.1038/ nature07201.

10. Nrf2-ARE pathway: An emerging target against oxidative stress and neuroinflammation in neurodegenerative diseases /I. Buendia, P. Michalska, E. Navarro [et al.] // Pharmacology and Therapeutics. - 2016. - 
No. 157. - P. 84-104. - Access mode : https://doi. org/10.1016/j.pharmthera.2015.11.003.

11. Solleiro-Villavicencio $\mathrm{H}$. Effect of chronic oxidative stress on neuroinflammatory response mediated by $\mathrm{CD} 4+\mathrm{T}$ cells in neurodegenerative diseases $/ \mathrm{H}$. SolleiroVillavicencio, S. Rivas-Arancibia // Frontiers in Cellular Neuroscience. - 2018. - No. 12. - P. 114. https://doi. org/10.3389/fncel.2018.00114.

12. Lushchak V. I. Free radicals, reactive oxygen species, oxidative stress and its classification / V. I. Lushchak // Chemico-Biological Interactions. - 2014. No. 224. - P. 164-175. - Access mode : https://doi. org/10.1016/j.cbi.2014.10.016.

13. Reactive oxygen species and mitochondria: A nexus of cellular homeostasis / J. Dan Dunn, L. A. Alvarez, X. Zhang, T. Soldati // Redox Biology. - 2015. - No. 6. P. 472-485. - Access mode : https://doi.org/https://doi. org/10.1016/j.redox.2015.09.005.

14. Banks W. A. The blood-brain barrier and immune function and dysfunction / W. A. Banks, M. A. Erickson // Neurobiology of Disease. - 2010. - No. 37. -P. 26-32. Access mode: https://doi.org/10.1016/j.nbd.2009.07.031.

15. Ray D. Immune senescence, epigenetics and autoimmunity / D. Ray, R. Yung // Clinical Immunology. 2018. - No. 196. - P. 59-63. - Access mode : https://doi. org/10.1016/j.clim.2018.04.002.

16. Lenz K. M. Microglia and beyond: innate immune cells as regulators of brain development and behavioral function / K. M. Lenz, L. H. Nelson // Frontiers in Immunology. - 2018. - No. 9. - P. 698. - Access mode : https:// doi.org/10.1016/0306-4522(90)90229-w.

17. Microglia express insulin-like growth factor-1 in the hippocampus of aged APPswe/PS1 $\triangle \mathrm{E} 9$ transgenic mice / C. L. Myhre, C. Thygesen, B. Villadsen [et al.] // Frontiers in Cellular Neuroscience. - 2019. - No. 13. P. 1-17. - Access mode : https://doi.org/10.3389/ fncel.2019.00308

18. Microglia promote learning-dependent synapse formation through brain-derived neurotrophic factor I C. N. Parkhurst, G. Yang, I. Ninan [et al.] // Cell. - 2013. No. 155. - P. 1596-1609. - Access mode : https://doi. org/10.1016/j.cell.2013.11.030.

19. Microglia actively remodel adult hippocampal neurogenesis through the phagocytosis secretome / I. Diaz-Aparicio, I. Paris, V. Sierra-Torre [et al.] // Journal of Neuroscience. - 2020. - No. 40. - P. 1453-1482.

20. 't Hart B. A. Commentary on special issue: CNS diseases and the immune system / B. A. 't Hart, W. F. den Dunnen // Journal of Neuroimmune Pharmacology: The Official Journal of the Society on Neurolmmune Pharmacology. - 2013. - No. 8. - P. 757-759.

21. 't Hart B. A. Multiple sclerosis - a response-todamage model / B. A. 't Hart, R. Q. Hintzen, J. D. Laman // Trends in Molecular Medicine. - 2009. - No. 15. P. 235-244. - Access mode : https://doi.org/10.1016/j. molmed.2009.04.001.

22. Male D. Adaptive immune responses in the CNS / D. Male // Neuroinflammation and CNS disorders / D. Male // 2014. - P. 37-57. - Access mode : https://doi. org/10.1002/9781118406557.ch3.

23. Sulforaphane - role in aging and neurodegeneration / R. Santín-Márquez, A. Alarcón-Aguilar, N. E. LópezDiazguerrero [et al.] // GeroScience. - 2019. - No. 41. P. 655-670. - Access mode : https://doi.org/10.1007/ s11357-019-00061-7.
24. Schain M. Neuroinflammation in neurodegenerative disorders-a review / M. Schain, W. C. Kreisl // Current Neurology and Neuroscience Reports. - 2017. No. 17. -Access mode : https://doi.org/10.1007/s11910017-0733-2.

25. Houghton C. A. Sulforaphane: Its "coming of age" as a clinically relevant nutraceutical in the prevention and treatment of chronic disease / C. A. Houghton. // Oxidative Medicine and Cellular Longevity. - 2019. - P. 1-27. Access mode : https://doi.org/10.1155/2019/2716870.

26. Lushchak V. I. Interplay between bioenergetics and oxidative stress at normal brain aging. Aging as a result of increasing disbalance in the system oxidative stress-energy provision / V. I. Lushchak // Pflügers Archiv - European Journal of Physiology. - 2021. Access mode : https://doi.org/10.1007/s00424-02102531-4.

27. Brasier A. R. The NF-kappaB regulatory network / A. R. Brasier // Cardiovascular Toxicology. - 2006. No. 6. - P. 111-130. - Access mode : https://doi. org/10.1385/ct:6:2:111.

28. Gilmore T. D. Introduction to NF-kB: Players, pathways, perspectives / T. D. Gilmore // Oncogene. 2006. - No. 25. - P. 6680-6684. -Access mode : https:// doi.org/10.1038/sj.onc.1209954.

29. Hayden M. S. NF-kB in immunobiology / M. S. Hayden, S. Ghosh // Cell Research. - 2011. No. 21. - P. 223-244. - Access mode : https://doi. org/10.1038/cr.2011.13.

30. Proteasome-dependent autoregulation of Bruton tyrosine kinase (Btk) promoter via NF-kappaB / L. Yu, A. J. Mohamed, O. E. Simonson [et al.] // Blood. -2008. No. 111. - P. 4617-4626. - Access mode : https://doi. org/10.1182/blood-2007-10-121137.

31. Giridharan S. Mechanisms of NF-KB p65 and strategies for therapeutic manipulation / S. Giridharan, M. Srinivasan // Journal of Inflammation Research. 2018. - No. 11. - P. 407-419. - Access mode : https:// doi.org/10.2147/JIR.S140188.

32. Chen J. Regulation of NF-kB by ubiquitination / J. Chen, Z. J. Chen // Current Opinion in Immunology. 2013. - No. 25. - P. 4-12. - Access mode : https://doi. org/10.1016/j.coi.2012.12.005.

33. Bonizzi G. The two NF-kappaB activation pathways and their role in innate and adaptive immunity / G. Bonizzi, M. Karin // Trends in Immunology. - 2004. No. 25. - P. 280-288. - Access mode : https://doi. org/10.1016/j.it.2004.03.008.

34. Mobeen A. Modeling the post-translational modifications and its effects in the NF-KB pathway / A. Mobeen, S. Ramachandran // BioRxiv. - 2020. Access mode: https://doi.org/10.1101/2020.02.13.947010.

35. Lipinski M. CBP/p300 in brain development and plasticity: disentangling the KAT's cradle / M. Lipinski, B. Del Blanco, A. Barco // Current Opinion in Neurobiology. - 2019. - No. 59. - P. 1-8. - Access mode : https:// doi.org/10.1016/j.conb.2019.01.023.

36. Hayden M. S. Shared principles in NF-kappaB signaling / M. S. Hayden, S. Ghosh // Cell. - 2008. No. 132. - P. 344-362. - Access mode : https://doi. org/10.1016/j.cell.2008.01.020.

37. Basak S. Generation and activation of multiple dimeric transcription factors within the NF-kappaB signaling system / S. Basak, V. F. Shih, A. Hoffmann // Molecular and Cellular Biology. - 2008. - No. 28. - 
P. 3139-3150. - Access mode : https://doi.org/10.1128/ MCB.01469-07.

38. Assar M. Diabetes and ageing-induced vascular inflammation / M. Assar, J. Angulo, L. Rodríguez-Mañas // Journal of Physiology. - 2016. - No. 594. - P. 21252146. -Access mode : https://doi.org/10.1113/JP270841.

39. The antioxidant properties of organosulfur compounds (sulforaphane)/S. de Figueiredo, N. Binda, J. Nogueira-Machado [et al.] // Recent Patents on Endocrine, Metabolic \& Immune Drug Discovery. 2015. - No. 9. - P. 24-39. - Access mode : https://doi org/10.2174/1872214809666150505164138.

40. The Keap1-Nrf2 pathway: Mechanisms of activation and dysregulation in cancer / E. Kansanen, S. M. Kuosmanen, H. Leinonen, A. L. Levonenn // Redox Biology. - 2013. - No. 1. - P. 45-49. - Access mode https://doi.org/10.1016/j.redox.2012.10.001.

41. Tonelli C. Transcriptional regulation by Nrf2 / C. Tonelli, I. I. Chio, D. A. Tuveson // Antioxidants \& Redox Signaling. - 2018. - No. 29. - P. 1727-1745. - Access mode : https://doi.org/10.1089/ars.2017.7342.

42. The Nrf2 cell defence pathway: Keap1-dependent and -independent mechanisms of regulation / H. K. Bryan, A. Olayanju, C. E. Goldring, B. K. Park // Biochemical Pharmacology. -2013. - No. 85. - P. 705-717. -Access mode : https://doi.org/https://doi.org/10.1016/j.bcp.2012.11.016.

43. The Nrf2-ARE pathway: An indicator and modulator of oxidative stress in neurodegeneration J. A. Johnson, D. A. Johnson, A. D. Kraft [et al.] // Annals of the New York Academy of Sciences. - 2008. No. 1147. - P. 61-69. - Access mode : https://doi. org/10.1196/annals.1427.036.

44. KPNA6 (Importin \{alpha\}7)-mediated nuclear import of Keap1 represses the Nrf2-dependent antioxidant response / Z. Sun, T. Wu, F. Zhao [et al.] // Molecular and Cellular Biology. - 2011. - No. 31. - P. 1800-1811. Access mode : https://doi.org/10.1128/MCB.05036-11.

45. Scaffolding of Keap1 to the actin cytoskeleton controls the function of Nrf2 as key regulator of cytoprotective phase 2 genes / M. Kang, A. Kobayashi, N. Wakabayashi [et al.] // Proceedings of the National Academy of Sciences of the United States of America. 2004. - No. 101. -P. 2046-2051. -Access mode : https:// doi.org/10.1073/pnas.0308347100.

46. Oxidative stress sensor keap1 functions as an adaptor for cul3-based e3 ligase to regulate proteasomal degradation of Nrf2 / A. Kobayashi, M. Kang, H. Okawa [et al.] // Molecular and Cellular Biology. - 2004. No. 24. - P. 7130-7139. - Access mode : https://doi. org/10.1128/mcb.24.16.7130-7139.2004.

47. Direct evidence that sulfhydryl groups of Keap1 are the sensors regulating induction of phase 2 enzymes that protect against carcinogens and oxidants / A. T. Dinkova-Kostova, W. D. Holtzclaw, R. N. Cole [et al.] // Proceedings of the National Academy of Sciences of the United States of America. - 2002. - No. 99. - P. 11908 11913. - Access mode : https://doi.org/10.1073/ pnas.172398899.

48. Prospective type 1 and type 2 disulfides of Keap1 protein / R. Holland, A. E. Hawkins, A. L. Eggler [et al.] // Chemical Research in Toxicology. - 2008. - No. 21. P. 2051-2060. - Access mode : https://doi.org/10.1021/ tx800226m

49. Holland R. Chemistry of the cysteine sensors in Kelch-like ECH-associated protein 1 / R. Holland,
J. C. Fishbein. // Antioxidants \& Redox Signaling. 2010. - No. 13. - P. 1749-1761. -Access mode : https:// doi.org/10.1089/ars.2010.3273.

50. Taguchi K. Molecular mechanisms of the Keap1Nrf2 pathway in stress response and cancer evolution / K. Taguchi, H. Motohashi, M. Yamamoto // Genes to Cells. - 2011. - No. 16. - P. 123-140. - Access mode : https://doi.org/10.1111/j.1365-2443.2010.01473.x.

51. Katsuoka F. Small Maf proteins (MafF, MafG, MafK): History, structure and function / F. Katsuoka, M. Yamamoto // Gene. - 2016. - No. 586. -P. 197-205. Access mode: https://doi.org/10.1016/j.gene.2016.03.058.

52. Oxidative stress and neuroinflammation potentiate each other to promote progression of dopamine neurodegeneration / J. He, G. Zhu, G. Wang, G. Zhang // Oxidative Medicine and Cellular Longevity. - 2020. No. 2020. - Access mode : https://doi.org/10.1155/ 2020/6137521.

53. Emerging promise of sulforaphane-mediated Nrf2 signaling cascade against neurological disorders / M. S. Uddin, A. Mamun, M. Jakaria [et al.] // Science of the Total Environment. - 2020. - No. 707. - Access mode : https://doi.org/10.1016/j.scitotenv.2019.135624.

54. Cruciferous vegetables intake and the risk of colorectal cancer: a meta-analysis of observational studies / Q. J. Wu, Y. Yang, E. Vogtmann [et al.] // Annals of Oncology: Official Journal of the European Society for Medical Oncology. - 2013. - No. 24. - P. 1079-1087. Access mode : https://doi.org/10.1093/annonc/mds601.

55. Cruciferous vegetables, isothiocyanates, and bladder cancer prevention / B. Abbaoui, C. R. Lucas, K. M. Riedl [et al.] // Molecular Nutrition \& Food Research. -2018. - No. 62. - P. e1800079. -Access mode : https://doi.org/10.1002/mnfr.201800079.

56. McNaughton S. A. Development of a food composition database for the estimation of dietary intakes of glucosinolates, the biologically active constituents of cruciferous vegetables / S. A. McNaughton, G. C. Marks // British Journal of Nutrition. - 2003. No. 90. - P. 687-697. - Access mode : https://doi. org/10.1079/bjn2003917.

57. Determination of sulforaphane in broccoli and cabbage by high-performance liquid chromatography I H. Liang, Q. P. Yuan, H. R. Dong, Y. M. Liu // Journal of Food Composition and Analysis. - 2006. - No. 19. P. 473-476. - Access mode : https://doi.org/10.1016/j. jfca.2005.11.005.

58. Han D. Separation and purification of sulforaphane from broccoli by solid phase extraction / D. Han, K. H. Row // International Journal of Molecular Sciences. 2011. - No. 12. - P. 1854-1861. -Access mode : https:// doi.org/10.3390/ijms12031854

59. High-efficiency purification of sulforaphane from the broccoli extract by nanostructured SBA-15 silica using solid-phase extraction method / S. M. Hafezian, S. N. Azizi, P. Biparva, A. Bekhradnia // Journal of Chromatography B: Analytical Technologies in the Biomedical and Life Sciences. - 2019. - No. 1108. - P. 1-10. https:// doi.org/10.1016/j.jchromb.2019.01.007.

60. Dietary intake of sulforaphane-rich broccoli sprout extracts during juvenile and adolescence can prevent phencyclidine-induced cognitive deficits at adulthood / Y. Shirai, Y. Fujita, R. Hashimoto [et al.] // PLoS ONE. 2015. - No. 10. - P. 1-22. - Access mode : https://doi. org/10.1371/journal.pone.0127244. 
61. Sulforaphane ameliorates okadaic acid-induced memory impairment in rats by activating the Nrf2/HO-1 antioxidant pathway / S. Dwivedi, N. Rajasekar, K. Hanif [et al.] // Molecular Neurobiology. - 2016. - No. 53. P. 5310-5323. - Access mode : = https://doi.org/10.1007/ s12035-015-9451-4.

62. Sulforaphane attenuates postnatal proteasome inhibition and improves spatial learning in adult mice / A. Sunkaria, S. Bhardwaj, A. Yadav [et al.] // Journal of
Nutritional Biochemistry. - 2018. - No. 51. - P. 69-79. Access mode : https://doi.org/10.1016/j.jnutbio.2017. 09.016.

63. Shati A. A. Hepatotoxic effect of subacute vincristine administration activates necrosis and intrinsic apoptosis in rats: protective roles of broccoli and Indian mustard / A. A. Shati, F. G. Elsaid // Archives of Physiology and Biochemistry. - 2019. - No. 125. - P. 1-11. - Access mode : https://doi.org/10.1080/13813455.2018.1427765.

\section{REFERENCES}

1. Vanduchova, A., Anzenbacher, P., \& Anzenbacherova, E. (2019). Isothiocyanate from broccoli, sulforaphane, and its properties. Journal of Medicinal Food, 22 (2), 121-126. Retrieved from: https://doi. org/10.1089/jmf.2018.0024.

2. Halkier, B.A., \& Gershenzon, J. (2006). Biology and biochemistry of glucosinolates. Annual Review of Plant Biology, 57, 303-333. Retrieved from: https://doi. org/10.1146/annurev.arplant.57.032905.105228.

3. Juge, N., Mithen, R.F., \& Traka, M. (2007). Molecular basis for chemoprevention by sulforaphane: A comprehensive review. Cellular and Molecular Life Sciences, 64 (9), 1105-1127. Retrieved from: https://doi. org/10.1007/s00018-007-6484-5.

4. Fischer, R., \& Maier, O. (2015). Interrelation of oxidative stress and inflammation in neurodegenerative disease: role of TNF. Oxidative Medicine and Cellular Longevity, 2015, 610813. Retrieved from: https://doi. org/10.1155/2015/610813.

5. Song, H., Sieurin, J., Wirdefeldt, K., Pedersen, N.L., Almqvist, C., Larsson, H., Valdimarsdóttir, U.A., \& Fang, F. (2020). Association of stress-related disorders with subsequent neurodegenerative diseases. JAMA Neurology, 77 (6), 700-709. Retrieved from: https://doi.org/ 10.1001/jamaneurol.2020.0117.

6. He, J., Zhu, G., Wang, G., \& Zhang, F. (2020). Oxidative stress and neuroinflammation potentiate each other to promote progression of dopamine neurodegeneration. Oxidative Medicine and Cellular Longevity, 2020, 6137521. Retrieved from: https://doi.org/10.1155/ 2020/6137521.

7. Blach-Olszewska, Z., \& Leszek, J. (2007). Mechanisms of over-activated innate immune system regulation in autoimmune and neurodegenerative disorders. Neuropsychiatric Disease and Treatment, 3 (3), 365-372.

8. Garaschuk, O., Semchyshyn, H.M., \& Lushchak, V.I. (2018). Healthy brain aging: Interplay between reactive species, inflammation and energy supply. Ageing Research Reviews, 43, 26-45. Retrieved from: https://doi. org/10.1016/j.arr.2018.02.003.

9. Medzhitov, R. (2008). Origin and physiological roles of inflammation. Nature, 454 (7203), 428-435. Retrieved from: https://doi.org/10.1038/nature07201.

10. Buendia, I., Michalska, P., Navarro, E., Gameiro, I., Egea, J., \& León, R. (2016). Nrf2-ARE pathway: An emerging target against oxidative stress and neuroinflammation in neurodegenerative diseases. Pharma- cology and Therapeutics, 157, 84-104. Retrieved from: https://doi.org/10.1016/j.pharmthera.2015.11.003.

11. Solleiro-Villavicencio, H., \& Rivas-Arancibia, S. (2018). Effect of chronic oxidative stress on neuroinflammatory response mediated by CD4+T cells in neurodegenerative diseases. Frontiers in Cellular Neuroscience, 12, 114. Retrieved from: https://doi.org/10.3389/ fncel.2018.00114.

12. Lushchak, V.I. (2014). Free radicals, reactive oxygen species, oxidative stress and its classification. Chemico-Biological Interactions, 224 (October), 164-175. Retrieved from: https://doi.org/10.1016/j.cbi.2014.10.016.

13. Dan Dunn, J., Alvarez, L.A.J., Zhang, X., \& Soldati, T. (2015). Reactive oxygen species and mitochondria: A nexus of cellular homeostasis. Redox Biology, 6, 472485. Retrieved from: https://doi.org/10.1016/j.redox. 2015.09.005

14.Banks, W.A., \& Erickson, M.A. (2010). The bloodbrain barrier and immune function and dysfunction. Neurobiology of Disease, 37 (1), 26-32. Retrieved from: https://doi.org/10.1016/j.nbd.2009.07.031.

15. Ray, D., \& Yung, R. (2018). Immune senescence, epigenetics and autoimmunity. Clinical Immunology, 196 (March), 59-63. Retrieved from: https://doi.org/10.1016/j. clim.2018.04.002.

16. Lenz, K.M., \& Nelson, L.H. (2018). Microglia and beyond: innate immune cells as regulators of brain development and behavioral function. Frontiers in Immunology, 9, 698. Retrieved from: https://doi.org/10.3389/ fimmu.2018.00698.

17. Myhre, C.L., Thygesen, C., Villadsen, B., Vollerup, J., Ilkjær, L., Krohn, K.T., Grebing, M., Zhao, S., Khan, A.M., Dissing-Olesen, L., Jensen, M.S., Babcock, A. A., \& Finsen, B. (2019). Microglia express insulinlike growth factor-1 in the hippocampus of aged APPswe/ PS1 1 E9 transgenic mice. Frontiers in Cellular Neuroscience, 13 (July), 1-17. Retrieved from: https://doi.org/ 10.3389/fncel.2019.00308.

18. Parkhurst, C.N., Yang, G., Ninan, I., Savas, J.N., Yates, J.R.3rd, Lafaille, J.J., Hempstead, B.L., Littman, D.R., \& Gan, W.-B. (2013). Microglia promote learning-dependent synapse formation through brainderived neurotrophic factor. Cell, 155 (7), 1596-1609. Retrieved from: https://doi.org/10.1016/j.cell.2013.11.030.

19. Diaz-Aparicio, I., Paris, I., Sierra-Torre, V., PlazaZabala, A., Rodríguez-Iglesias, N., Márquez-Ropero, M., Beccari, S., et al. (2020). Microglia actively remodel adult 
hippocampal neurogenesis through the phagocytosis secretome. Journal of Neuroscience, 40 (7), 1453-1482. Retrieved from: https://doi.org/10.1523/JNEUROSCI. 0993-19.2019.

20. 't Hart, B.A., \& den Dunnen, W.F. (2013). Commentary on special issue: CNS diseases and the immune system. Journal of Neuroimmune Pharmacology: The Official Journal of the Society on Neurolmmune Pharmacology, 8 (4), 757-759. Retrieved from: https://doi. org/10.1007/s11481-013-9486-0.

21. 't Hart, B.A., Hintzen, R.Q., \& Laman, J D. (2009). Multiple sclerosis - a response-to-damage model. Trends in Molecular Medicine, 15 (6), 235-244. Retrieved from: https://doi.org/10.1016/j.molmed.2009.04.001.

22. Male, D. (2014). Adaptive immune responses in the CNS. In neuroinflammation and CNS disorders (pp. 37-57). John Wiley \& Sons, Ltd. Retrieved from: https:// doi.org/10.1002/9781118406557.ch3.

23. Santín-Márquez, R., Alarcón-Aguilar, A., LópezDiazguerrero, N.E., Chondrogianni, N., \& Königsberg, M. (2019). Sulforaphane-role in aging and neurodegeneration. GeroScience, 41 (5), 655-670. Retrieved from: https:// doi.org/10.1007/s11357-019-00061-7.

24. Schain, M., \& Kreisl, W.C. (2017). Neuroinflammation in neurodegenerative disorders - a review. Current Neurology and Neuroscience Reports, 17 (3). Retrieved from: https://doi.org/10.1007/s11910-017-0733-2.

25. Houghton, C.A. (2019). Sulforaphane: Its "coming of age" as a clinically relevant nutraceutical in the prevention and treatment of chronic disease. Oxidative Medicine and Cellular Longevity. Retrieved from: https:// doi.org/10.1155/2019/2716870.

26. Lushchak, V.I. (2021). Interplay between bioenergetics and oxidative stress at normal brain aging. Aging as a result of increasing disbalance in the system oxidative stress-energy provision. Pflügers Archiv European Journal of Physiology. Retrieved from: https:// doi.org/10.1007/s00424-021-02531-4.

27. Brasier, A.R. (2006). The NF-kappaB regulatory network. Cardiovascular Toxicology, 6 (2), 111-130. Retrieved from: https://doi.org/10.1385/ct:6:2:111.

28. Gilmore, T.D. (2006). Introduction to NF-kB: Players, pathways, perspectives. Oncogene, 25 (51), 6680-6684. Retrieved from: https://doi.org/10.1038/sj. onc.1209954.

29. Hayden, M.S., \& Ghosh, S. (2011). NF-kB in immunobiology. Cell Research, 21 (2), 223-244. Retrieved from: https://doi.org/10.1038/cr.2011.13.

30. Yu, L., Mohamed, A.J., Simonson, O.E., Vargas, L., Blomberg, K.E.M., Björkstrand, B., Arteaga, H.J., Nore, B.F., \& Smith, C.I.E. (2008). Proteasome-dependent autoregulation of Bruton tyrosine kinase (Btk) promoter via NF-kappaB. Blood, 111 (9), 4617-4626. Retrieved from: https://doi.org/10.1182/blood-2007-10-121137.

31. Giridharan, S., \& Srinivasan, M. (2018). Mechanisms of NF-KB p65 and strategies for therapeutic manipulation. Journal of Inflammation Research, 11 407-419. Retrieved from: https://doi.org/10.2147/JIR. S140188.

32. Chen, J., \& Chen, Z.J. (2013). Regulation of NF-kB by ubiquitination. Current Opinion in Immunology, 25 (1), 4-12. Retrieved from: https://doi.org/10.1016/j. coi.2012.12.005.

33. Bonizzi, G., \& Karin, M. (2004). The two NFkappaB activation pathways and their role in innate and adaptive immunity. Trends in Immunology, 25 (6), 280-288. Retrieved from: https://doi.org/10.1016/j.it.2004.03.008.

34. Mobeen, A., \& Ramachandran, S. (2020). Modeling the post-translational modifications and its effects in the NF-KB pathway. BioRxiv. Retrieved from: https://doi.org/10.1101/2020.02.13.947010.

35. Lipinski, M., Del Blanco, B., \& Barco, A. (2019). $\mathrm{CBP} / \mathrm{p} 300$ in brain development and plasticity: disentangling the KAT's cradle. Current Opinion in Neurobiology, 59, 1-8. Retrieved from: https://doi.org/10.1016/j. conb.2019.01.023.

36. Hayden, M.S., \& Ghosh, S. (2008). Shared principles in NF-kappaB signaling. Cell, 132 (3), 344-362. Retrieved from: https://doi.org/10.1016/j.cell.2008.01.020.

37. Basak, S., Shih, V.F.-S., \& Hoffmann, A. (2008). Generation and activation of multiple dimeric transcription factors within the NF-kappaB signaling system. Molecular and Cellular Biology, 28 (10), 3139-3150. Retrieved from: https://doi.org/10.1128/MCB.01469-07.

38. Assar, M. El, Angulo, J., \& Rodríguez-Mañas, L. (2016). Diabetes and ageing-induced vascular inflammation. Journal of Physiology, 594 (8), 2125-2146. Retrieved from: https://doi.org/10.1113/JP270841.

39. de Figueiredo, S., Binda, N., Nogueira-Machado, J., Vieira-Filho, S., \& Caligiorne, R. (2015). The antioxidant properties of organosulfur compounds (sulforaphane). Recent Patents on Endocrine, Metabolic \& Immune Drug Discovery, 9 (1), 24-39. Retrieved from: https://doi.org/10.2174/1872214809666150505164138.

40. Kansanen, E., Kuosmanen, S. M., Leinonen, H., \& Levonenn, A.L. (2013). The Keap1-Nrf2 pathway: Mechanisms of activation and dysregulation in cancer. Redox Biology, 1 (1), 45-49. Retrieved from: https://doi. org/10.1016/j.redox.2012.10.001.

41. Tonelli, C., Chio, I.I.C., \& Tuveson, D.A. (2018). Transcriptional regulation by Nrf2. Antioxidants \& Redox Signaling, 29 (17), 1727-1745. Retrieved from: https:// doi.org/10.1089/ars.2017.7342.

42. Bryan, H.K., Olayanju, A., Goldring, C.E., \& Park, B.K. (2013). The Nrf2 cell defence pathway: Keap1dependent and -independent mechanisms of regulation. Biochemical Pharmacology, 85 (6), 705-717. Retrieved from: https://doi.org/10.1016/j.bcp.2012.11.016.

43. Johnson, J.A., Johnson, D.A., Kraft, A.D., Calkins, M.J., Jakel, R.J., Vargas, M.R., \& Chen, P.C. (2008). The Nrf2-ARE pathway: An indicator and modulator of oxidative stress in neurodegeneration. Annals of the New York Academy of Sciences, 1147, 61-69. Retrieved from: https://doi.org/10.1196/annals.1427.036.

44. Sun, Z., Wu, T., Zhao, F., Lau, A., Birch, C.M., \& Zhang, D.D. (2011). KPNA6 (Importin \{alpha\}7)-mediated nuclear import of Keap1 represses the Nrf2-dependent antioxidant response. Molecular and Cellular Biology, 31 (9), 1800-1811. Retrieved from: https://doi.org/10.1128/ MCB.05036-11.

45. Kang, M.-I., Kobayashi, A., Wakabayashi, N., Kim, S.-G., \& Yamamoto, M. (2004). Scaffolding of Keap1 to the actin cytoskeleton controls the function of Nrf2 as key regulator of cytoprotective phase 2 genes. Proceedings of the National Academy of Sciences of the United States of America, 101 (7), 2046-2051. Retrieved from: https:// doi.org/10.1073/pnas.0308347100.

46. Kobayashi, A., Kang, M.-I., Okawa, H., Ohtsuji, M., Zenke, Y., Chiba, T., Igarashi, K., \& Yamamoto, M. (2004). Oxidative stress sensor keap1 functions as an adaptor 
for cul3-based e3 ligase to regulate proteasomal degradation of nrf2. Molecular and Cellular Biology, 24 (16), 7130-7139. Retrieved from: https://doi.org/10.1128/ mcb.24.16.7130-7139.2004.

47. Dinkova-Kostova, A.T., Holtzclaw, W.D., Cole, R.N., Itoh, K., Wakabayashi, N., Katoh, Y., Yamamoto, M., \& Talalay, P. (2002). Direct evidence that sulfhydryl groups of Keap1 are the sensors regulating induction of phase 2 enzymes that protect against carcinogens and oxidants. Proceedings of the National Academy of Sciences of the United States of America, 99 (18), 11908-11913. Retrieved from: https://doi. org/10.1073/pnas.172398899.

48. Holland, R., Hawkins, A.E., Eggler, A.L., Mesecar, A.D., Fabris, D., \& Fishbein, J.C. (2008). Prospective type 1 and type 2 disulfides of Keap1 protein. Chemical Research in Toxicology, 21 (10), 2051-2060. Retrieved from: https://doi.org/10.1021/tx800226m.

49. Holland, R., \& Fishbein, J.C. (2010). Chemistry of the cysteine sensors in Kelch-like $\mathrm{ECH}$-associated protein 1. Antioxidants \& Redox Signaling, 13 (11), 17491761. Retrieved from: https://doi.org/10.1089/ars.2010. 3273.

50. Taguchi, K., Motohashi, H., \& Yamamoto, M. (2011). Molecular mechanisms of the Keap1-Nrf2 pathway in stress response and cancer evolution. Genes to Cells, 16 (2), 123-140. Retrieved from: https://doi. org/10.1111/j.1365-2443.2010.01473.x.

51. Katsuoka, F., \& Yamamoto, M. (2016). Small Maf proteins (MafF, MafG, MafK): History, structure and function. Gene, 586 (2), 197-205. Retrieved from: https:// doi.org/10.1016/j.gene.2016.03.058.

52. He, J., Zhu, G., Wang, G., \& Zhang, F. (2020). Oxidative stress and neuroinflammation potentiate each other to promote progression of dopamine neurodegeneration. Oxidative Medicine and Cellular Longevity, 2020, 6137521. Retrieved from: https://doi.org/10.1155/ 2020/6137521.

53. Uddin, M.S., Mamun, A.Al, Jakaria, M., Thangapandiyan, S., Ahmad, J., Rahman, M.A., Mathew, B., Abdel-Daim, M.M., \&Aleya, L. (2020). Emerging promise of sulforaphane-mediated Nrf2 signaling cascade against neurological disorders. Science of the Total Environment, 707, 135624. Retrieved from: https://doi.org/10.1016/j. scitotenv.2019.135624.

54. Wu, Q.J., Yang, Y., Vogtmann, E., Wang, J., Han, L.H., Li, H.L., \& Xiang, Y.B. (2013). Cruciferous vegetables intake and the risk of colorectal cancer: a meta-analysis of observational studies. Annals of Oncology: Official Journal of the European Society for Medical Oncology, 24 (4), 1079-1087. Retrieved from: https://doi.org/10.1093/annonc/mds601.

55. Abbaoui, B., Lucas, C.R., Riedl, K.M., Clinton, S.K., \& Mortazavi, A. (2018). Cruciferous vegetables, isothio- cyanates, and bladder cancer prevention. Molecular Nutrition \& Food Research, 62 (18), e1800079. Retrieved from: https://doi.org/10.1002/mnfr.201800079.

56. McNaughton, S.A., \& Marks, G.C. (2003). Development of a food composition database for the estimation of dietary intakes of glucosinolates, the biologically active constituents of cruciferous vegetables. British Journal of Nutrition, 90 (3), 687-697. Retrieved from: https://doi.org/10.1079/bjn2003917.

57. Liang, H., Yuan, Q.P., Dong, H.R., \& Liu, Y.M. (2006). Determination of sulforaphane in broccoli and cabbage by high-performance liquid chromatography. Journal of Food Composition and Analysis, 19 (5), 473476. Retrieved from: https://doi.org/10.1016/j.jfca. 2005.11.005.

58. Han, D., \& Row, K.H. (2011). Separation and purification of sulforaphane from broccoli by solid phase extraction. International Journal of Molecular Sciences, 12 (3), 1854-1861. Retrieved from: https://doi.org/10.3390/ ijms12031854.

59. Hafezian, S.M., Azizi, S.N., Biparva, P., \& Bekhradnia, A. (2019). High-efficiency purification of sulforaphane from the broccoli extract by nanostructured SBA-15 silica using solid-phase extraction method. Journal of Chromatography B: Analytical Technologies in the Biomedical and Life Sciences, 1108 (December 2018), 1-10. Retrieved from: https://doi.org/10.1016/j. jchromb.2019.01.007.

60. Shirai, Y., Fujita, Y., Hashimoto, R., Ohi, K., Yamamori, H., Yasuda, Y., Ishima, T., Suganuma, H., Ushida, Y., Takeda, M., \& Hashimoto, K. (2015). Dietary intake of sulforaphane-rich broccoli sprout extracts during juvenile and adolescence can prevent phencyclidineinduced cognitive deficits at adulthood. PLOS ONE, 10 (6), 1-22. Retrieved from: https://doi.org/10.1371/journal. pone.0127244.

61. Dwivedi, S., Rajasekar, N., Hanif, K., Nath, C., \& Shukla, R. (2016). Sulforaphane ameliorates okadaic acid-induced memory impairment in rats by activating the Nrf2/HO-1 antioxidant pathway. Molecular Neurobiology, 53 (8), 5310-5323. Retrieved from: https://doi.org/10.1007/ s12035-015-9451-4.

62. Sunkaria, A., Bhardwaj, S., Yadav, A., Halder, A., \& Sandhir, R. (2018). Sulforaphane attenuates postnatal proteasome inhibition and improves spatial learning in adult mice. Journal of Nutritional Biochemistry, 51, 69-79. Retrieved from: https://doi.org/10.1016/j.jnutbio.2017. 09.016.

63. Shati, A.A., \& Elsaid, F.G. (2019). Hepatotoxic effect of subacute vincristine administration activates necrosis and intrinsic apoptosis in rats: protective roles of broccoli and Indian mustard. Archives of Physiology and Biochemistry, 125 (1), 1-11. Retrieved from: https:// doi.org/10.1080/13813455.2018.1427765. 


\title{
ПОТЕНЦЙНЕ ВИКОРИСТАННЯ СУЛЬФОРАФАНУ ЯК НЕЙРОПРОТЕКТОРА
}

\begin{abstract}
Резюме
Вступ. За звичайних умов інтенсивність як оксидативного стресу, так і прозапальних процесів перебуває упевних межах. Однак під час розвитку нейрозапалення і надлишкового утворення активних форм кисню гомеостаз порушується, що спричиняє розвиток хвороби Альцгеймера, хвороби Паркінсона та інших нейродегенеративних розладів. Запальні процеси, викликані активацією імунної системи, можуть призвести до нейродегенеративних порушень. Сульфрорафран - це сполука з групи ізотіоціанатів, яка має потенціал для лікування нейродегенеративних розладів. Його терапевтичний вплив базується на здатності даної речовини активувати транскрипцію генів, які регулюють захисну активність клітин. Важливість робіт у цьому керунку зумовлена тим, що хвороба Альцгеймера та інші деменції займають сьоме місце серед провідних причин смерті у світі. у цій оглядовій статті обговорюються протизапальна дія сульфорафрану в головному мозку та його використання як потенційного нейропротектора у лікуванні нейродегенеративних захворювань.

Мета дослідження - проаналізувати сучасні джерела літератури щодо використання сульфрорафрану в медичній практиці задля його потенційного застосування з метою профрілактики або пом'якшення нейрозапальних процесів.

Висновки. Економічний і технологічний прогрес привів до поліпшення загальної якості життя та подовження його тривалості. Але досягнення у довголітті ставлять перед нами нові виклики. Якщо в молодому та зрілому віці організм добре підтримує гомеостаз, то в старших людей інтенсифрікація оксидативних і запальних процесів може призвести до розвитку деменцій та психічних розладів. Одним із кандидатів для боротьби за ясний розум у старості є сульфорафан. У цьому огляді його розглянуто як потенційний нейропротектор. Біологічно активні добавки і препарати на основі сульфорафрану здатні зменшувати запальні процеси у головному мозку та в організмі загалом, а тому їх можна застосовувати для профрілактики і лікування нейродегенеративних захворювань.
\end{abstract}

КЛЮЧОВІ СЛОВА: нейропротектор; сульфорафан; нейрозапалення; нейродегенеративні захворювання.

\author{
С. А. Цюмпала ${ }^{1}$, Е. М. Старчевская ${ }^{1}$, В. И. Лущак ${ }^{1,2,3}$ \\ ПРИКАРПАТСКИЙ НАЦИОНАЛЬНЫЙ УНИВЕРСИТЕТ ИМЕНИ ВАСИЛИЯ СТЕФАНИКА \\ ИВАНО-ФРАНКОВСК \\ ТЕРНОПОЛЬСКИЙ НАЦИОНАЛЬНЫЙ МЕДИЦИНСКИЙ УНИВЕРСИТЕТ ИМЕНИ И. Я. ГОРБАЧЕВСКОГО \\ МОЗ УКРАИНЫ ${ }^{2}$ \\ УНИВЕРСИТЕТ ИССЛЕДОВАНИЙ И РАЗРАБОТОК
}

\section{ПОТЕНЦИАЛЬНОЕ ИСПОЛЬЗОВАНИЕ СУЛЬФОРАФАНА КАК НЕЙРОПРОТЕКТОРА}

\section{Резюме}

Вступление. В обычных условиях интенсивность как оксидативного стресса, так и провоспалительных процессов находится в определенных пределах. Однако во время развития нейровоспаления и избыточного образования активных фрорм кислорода гомеостаз нарушается, что является причиной развития болезни Альцгеймера, болезни Паркинсона и других нейродегенеративных расстройств. Воспалительные процессы, вызванные активацией иммунной системы, могут привести к нейродегенеративным нарушениям. Сульфорафан - это соединение из группы изотиоцианатов, которое имеет потенциал для лечения нейродегенеративных расстройств. Его терапевтическое влияние базируется на способности данного вещества активировать транскрипцию генов, регулирующих защитную активность 
клеток. Важность работ в этом направлении обусловлена тем, что болезнь Альцгеймера и другие деменции занимают седьмое место среди ведущих причин смерти в мире. В этой обзорной статье обсуждаются противовоспалительное действие сульфрорафрана в головном мозге и его использование в качестве потенциального нейропротектора в лечении нейродегенеративных заболеваний.

Цель исследования - проанализировать современные источники литературы относительно использования сульфрорафана в медицинской практике для его потенциального применения с целью профилактики или смягчения нейровоспалительных процессов.

Выводы. Экономический и технологический прогресс привел к улучшению общего качества жизни и увеличению его продолжительности. Но достижения в долголетии ставят перед нами новые вызовы. Если в молодом и зрелом возрасте организм хорошо поддерживает гомеостаз, то в старших людей интенсификация оксидативных и воспалительных процессов может привести к развитию деменций и психических расстройств. Одним из кандидатов для борьбы за ясный ум в старости является сульфорафран. В этом обзоре его рассмотрено как потенциальный нейропротектор. Биологически активные добавки и препараты на основе сульфорафана способны уменьшать воспалительные процессы в головном мозге и в организме в целом, а поэтому их можно применять для профрилактики и лечения нейродегенеративных заболеваний.

КЛЮЧЕВЫЕ СЛОВА: нейропротектор; сульфорафан; нейровоспаление; нейродегенеративные заболевания.

Received 26.02.21

Address for correspondence: V. I. Lushchak, Vasyl Stefanyk Precarpathian National University, Shevchenko Str. 57, Ivano-Frankivsk, 76018, Ukraine, e-mail: volodymyr.lushchak@pnu.edu.ua. 